\title{
Review \\ Small Non-Coding RNAs in Leukemia
}

\author{
Veronica Balatti ${ }^{1,2, *}$ and Carlo M. Croce ${ }^{1,2, *}$
}

1 Department of Cancer Biology and Medical Genetics, The Ohio State University, Columbus, OH 43210, USA

2 The Ohio State University Comprehensive Cancer Center, The Ohio State University, Columbus, $\mathrm{OH} 43210$, USA

* Correspondence: Veronica.Balatti@osumc.edu (V.B.); carlo.croce@osumc.edu (C.M.C.); Tel.: +614-292-0654 (V.B.); +614-292-3063 (C.M.C.)

Simple Summary: Leukemia is a group of blood cancers that arise when abnormal or underdeveloped blood cells accumulate in the bloodstream, bone marrow and lymphatic system. A driver event in the development of Chronic Lymphocytic Leukemia (CLL) is the deletion of the genomic region encoding for $m i R-15 a / 16-1$. MicroRNAs are small non-coding RNAs involved in the regulation of gene expression, and loss of miR-15a/16-1 in CLL results in the accumulation of the antiapoptotic gene $B C L 2$ and inhibition of the apoptotic process. This discovery was the first evidence that microRNAs have a role in the onset of cancer. Following this finding, several studies investigated the role of microRNAs and other small non-coding RNAs in different types of leukemia and cancers in general. This review summarizes the role of small non-coding RNAs in leukemia and describes their possible application in clinical settings as biomarkers and/or targets for therapy.

check for updates

Citation: Balatti, V.; Croce, C.M. Small Non-Coding RNAs in Leukemia. Cancers 2022, 14, 509. https://doi.org/10.3390/ cancers14030509

Academic Editors: Gabriella Misso, Angela Lombardi and Agostino Festa

Received: 29 November 2021

Accepted: 14 January 2022

Published: 20 January 2022

Publisher's Note: MDPI stays neutral with regard to jurisdictional claims in published maps and institutional affiliations.

Copyright: (c) 2022 by the authors. Licensee MDPI, Basel, Switzerland. This article is an open access article distributed under the terms and conditions of the Creative Commons Attribution (CC BY) license (https:// creativecommons.org/licenses/by/ $4.0 /)$.

\begin{abstract}
In 2020, more than 60,500 people were diagnosed with leukemia in the USA, and more than 23,000 died. The incidence of leukemia is still rising, and drug resistance development is a serious concern for patients' wellbeing and survival. In the past two decades, small non-coding RNAs have been studied to evaluate their functions and possible role in cancer pathogenesis. Small non-coding RNAs are short RNA molecules involved in several cellular processes by regulating the expression of genes. An increasing body of evidence collected by many independent studies shows that the expression of these molecules is tissue specific, and that their dysregulation alters the expression of genes involved in tumor development, progression and drug response. Indeed, small non-coding RNAs play a pivotal role in the onset, staging, relapse and drug response of hematological malignancies and cancers in general. These findings strongly suggest that small non-coding RNAs could function as biomarkers and possible targets for therapy. Thus, in this review, we summarize the regulatory mechanisms of small non-coding RNA expression in different types of leukemia and assess their potential clinical implications.
\end{abstract}

Keywords: leukemia; small non-coding RNAs; microRNA; miRNA; tRNA fragments

\section{Background}

Leukemia arises as a consequence of the accumulation of underdeveloped or abnormal leukocytes in the blood and bone marrow. Leukemia is classified in a variety of groups traditionally based on clinical presentation (acute or chronic) and cell of origin lineage (lymphocytic or myelogenous) [1]. Acute leukemia arises quickly with a rapid onset of symptoms and is characterized by the accumulation of poorly differentiated blast cells. In contrast, chronic leukemia develops slowly with a gradual onset of symptoms and is characterized by the accumulation of more mature yet dysfunctional cells. Since hematopoietic stem cells generate lymphoid cells (including T cells, B cells and natural killer cells) and myeloid cells (including monocytes, macrophages, neutrophils, basophils, eosinophils, ery- 
throcytes and megakaryocytes), the major subtypes of leukemia are traditionally classified into four classes:

(1) Chronic lymphocytic leukemia (CLL) is the most common human leukemia, characterized by the accumulation of incompetent CD5+ B lymphocytes. Most CLL cases occur in the elderly when mature yet abnormal lymphoid cells undergo hyperplasia, leading to the development of a monoclonal population of dysfunctional lymphocytes [2].

(2) Acute lymphocytic leukemia (ALL) constitutes a family of genetically heterogeneous lymphoid neoplasms derived from B and T lymphoid progenitors [3]. Most ALL cases occur in children, when lymphoid blasts replicate without developing into normal B and T cells [4].

(3) Acute myeloid leukemia (AML) is a heterogeneous clonal disorder characterized by the proliferation of myeloid blasts and bone marrow failure and is the most common acute leukemia in adults [5].

(4) Chronic myeloid leukemia (CML) develops from a clonal myeloproliferative expansion of transformed hematopoietic myeloid cells of monocytic, erythroid and megakaryocytic lineages. Most CML cases occur in people between the ages of 25 and 60 when monoclonal populations of self-renewing, dysfunctional myeloid cells undergo hyperplasia [6].

These malignancies share similarities; however, AML, ALL and chronic lymphoproliferative and myeloproliferative neoplasms are extremely diverse cancers based on cell of origin, biology and clinical management [7]. Indeed, specific chromosomal aberrations lead to the activation of proto-oncogenes or loss of tumor suppressor genes [8-10]. A milestone in the field of chromosomal abnormalities in cancer occurred in 1960, with the publication of the first article by Nowell and Hungerford describing the association of CML with the presence of a small-size chromosome, known today as the Philadelphia ( $\mathrm{Ph}$ ) chromosome. The detection of the Philadelphia chromosome established, for the first time, that chromosome abnormalities in leukemia are acquired and thus a hallmark of neoplastic cells [11]. Following this discovery, substantial effort has been made to understand the molecular mechanism driving the development of such malignancies and provide effective treatment [12-14]. Remarkably, the study of distinctive chromosomal aberrations in CLL led to the astonishing discovery that microRNA genes (miRNAs) have a key role in the onset and progression of cancer [15]. The first evidence that miRNAs are involved in cancer was published by our group in 2002, describing the loss of miR-15a/16-1 in CLL [15,16]. In 2005, we showed that miR-15a/16-1 regulates the expression of BCL2, an essential antiapoptotic gene [17]. Since 2002, the study of small non-coding RNAs (ncRNAs) has guided modulation of gene expression in both physiological and pathological processes and laid the groundwork for the development of the most innovative detection tools and targeted therapies [18-20]. Indeed, genomic alterations in cancer cells can affect miRNA loci or other ncRNAs, and disruption of such mechanisms can lead to the dysregulation of genes that may promote survival or hinder apoptosis [17,21-24]. Following the first discoveries of Dr. Croce's group on miRNA dysregulation in CLL, Lu et al. developed an miRNA microarray to analyze miRNA profiles in samples from cancer patients [25]. The examination of over 300 cancer samples led to the discovery that miRNA expression profiles classify human cancers according to lineage and differentiation state [25]. Later on, other small non-coding RNAs were also found to be involved in cancer [23,26-28]. This review reports the story of such discoveries, describes the molecular mechanism of the most significant non-coding genes and revises their most recent applications in the treatment of patients.

\section{2. miRNA Biogenesis}

miRNA genes are transcribed by RNA polymerase II into long precursors (pri-miRNA) that are processed by the microprocessor complex (Drosha and DGCR8) into hairpin-shaped RNAs (pre-miR) and exported to the cytoplasm by exportin 5 (EXP5) [29]. In the cytoplasm, pre-miRNAs are cleaved by Dicer and loaded onto Argonaut proteins to form the pre-RISC complex [30]. The duplex structure is unwound, and the seed region at the $5^{\prime}$ ends of the 
'guide' (mature) miRNA strand is presented to scan for partial complementary sequences on mRNAs' $3^{\prime}$ UTRs [31,32]. The binding of the 3'UTRs of mRNAs to an miRNA seed region causes mRNA degradation and/or inhibits mRNA translation, resulting in decreased levels of gene expression [32]. This mechanism is responsible for fine-tuning the expression of genes, and it is a fundamental process for cells' commitment, differentiation, response to stimuli and apoptosis [33].

\section{3. miRNAs in Leukemia}

\section{1. miRNAs in CLL}

B cell chronic lymphocytic leukemia (CLL) is the most common human leukemia in the Western world [2]. CLL can occur in an indolent or aggressive form, both characterized by the accumulation of CD5+ B lymphocytes with specific genetic abnormalities [2]. Prognostic markers such as a high expression of unmutated immunoglobulin heavy variable genes (UM-Ig-VH) and a high level of $70 \mathrm{kD}$ zeta-associated protein (ZAP70) are associated with an unfavorable prognosis [34]. Additionally, chromosomal alterations are identified in more than $80 \%$ of cases and are used to stratify patients in risk groups: (i) low risk: normal karyotype or $13 \mathrm{q}$ deletion; (ii) intermediate risk: $11 \mathrm{q}$ deletion or trisomy 12 ; and (iii) high risk: 17p deletion or complex karyotype [35,36]. Many CLL cases show discordant prognostic factors $[37,38]$; thus, the identification of new parameters to establish the clinical outcome and to provide knowledge for the development of new therapeutic strategies is essential.

The study of chromosomal alteration in CLL led to the discovery that miRNAs have a key role in cancer and could function as biomarkers and possible targets for treatment [15,39] (Table 1).

Table 1. Differentially expressed small non-coding RNAs in chronic and acute human leukemias.

\begin{tabular}{|c|c|c|c|}
\hline miRNA & Expression & Biomarker & Reference \\
\hline let-7e & lower in ALL blast vs. BMC & $\begin{array}{l}\text { lower expression associates with poor } \\
\text { prognosis in ALL }\end{array}$ & {$[40]$} \\
\hline $\operatorname{miR}-100$ & $\begin{array}{l}\text { lower in ALL blast vs. BMC, higher in } \\
\text { ALL with } t(12 ; 21) \text { vs. other groups }\end{array}$ & $\begin{array}{l}\text { lower expression associates with poor } \\
\text { prognosis in ALL }\end{array}$ & {$[40,41]$} \\
\hline $\operatorname{miR}-125 a$ & $\begin{array}{l}\text { higher in CLL patients that develop } \\
\text { Richter's syndome }\end{array}$ & $\begin{array}{l}\text { biomarker for Richter trasformation in } \\
\text { CLL }\end{array}$ & [42] \\
\hline miR-125b-1 & $\begin{array}{l}\text { higher in newly diagnosed childhood } \\
\text { ALL vs. controls, higher in T-ALL vs. } \\
\text { other ALLs }\end{array}$ & biomarker for ALL & [43] \\
\hline $\operatorname{miR}-142-3 p$ & lowered by imatinib treatment in CML & biomarker for TKI response in CML & [44] \\
\hline miR-146a & increased by imatinib treatment in CML & biomarker for TKI response in CML & [44] \\
\hline miR-150 & increased by imatinib treatment in CML & $\begin{array}{l}\text { biomarker for TKI response in CML, } \\
\text { lower expression associates with poor } \\
\text { prognosis and staging }\end{array}$ & [44-51] \\
\hline $\operatorname{miR}-15 a / 16-1$ & $\begin{array}{l}\text { deleted in most CLL cases, lower in } \\
\text { AML vs. MDS and controls }\end{array}$ & $\begin{array}{l}\text { driver event in CLL onset, interacts } \\
\text { with other chromosomal alterations in } \\
\text { CLL prognosis, biomarker for } \\
\text { sensitivity to venetoclax }\end{array}$ & {$[15-17,39,52-55]$} \\
\hline $\operatorname{miR}-15 b / 16-2$ & lower in AML vs. MDS and controls & $\begin{array}{l}\text { promotes B cell malignancies, driver } \\
\text { event in AML pathogenesis, predicts } \\
\text { progression from MDS to AML }\end{array}$ & [53-55] \\
\hline miR-17-92 & $\begin{array}{l}\text { overexpressed in AML patients with } \\
\text { MLL rearrangements }\end{array}$ & & [56] \\
\hline
\end{tabular}


Table 1. Cont.

\begin{tabular}{|c|c|c|c|}
\hline miRNA & Expression & Biomarker & Reference \\
\hline miR-181a & $\begin{array}{l}\text { lower in ALL with } \mathrm{t}(12,21) \text { vs. pre-B } \\
\text { ALL, higher in exosomes from ALL vs. } \\
\text { heathy donors }\end{array}$ & involved in ALL pathogenesis & [57-60] \\
\hline $\operatorname{miR}-181 b$ & $\begin{array}{l}\text { drops during CLL progerssion and is } \\
\text { lower in relapsed/refractory AML }\end{array}$ & marker for CLL progression & {$[53,61]$} \\
\hline miR-196b & lower in ALL blast vs. BMC & biomarker for ALL & [40] \\
\hline miR-199b-5p & lowered by imatinib treatment in CML & biomarker for TKI response in CML & [44] \\
\hline miR-203 & $\begin{array}{l}\text { lower in newly diagnosed childhood } \\
\text { ALL vs. controls }\end{array}$ & biomarker for ALL & [43] \\
\hline $\operatorname{miR}-221$ & higher in DC56+T-ALL & $\begin{array}{l}\text { high expression associates with poor } \\
\text { prognosis }\end{array}$ & [62] \\
\hline miR-224 & overexpressed in $\mathrm{t}(15 ; 17)$ AMLs & & {$[56]$} \\
\hline $\mathrm{miR}-29 \mathrm{a} / \mathrm{b}$ & $\begin{array}{l}\text { overexpressed in all CLL vs. normal B } \\
\text { cells and in idolent vs. aggressive CLL, } \\
\text { dysregulated/mutated in AML }\end{array}$ & marker for CLL staging & {$[18,63-65]$} \\
\hline miR-34a & $\begin{array}{l}\text { lower in refractory CLL and in CLL } \\
\text { patients that develop Richter's } \\
\text { syndome, lower in AML with lost } \\
\text { C/EBP } \alpha\end{array}$ & $\begin{array}{l}\text { biomarker for Richter trasformation in } \\
\text { CLL and resistance development }\end{array}$ & {$[42,66-68]$} \\
\hline $\mathrm{miR}-34 \mathrm{~b} / \mathrm{c}$ & lost in 11q- CLL & $\begin{array}{l}\text { targets ZAP70, a prognostic marker in } \\
\text { CLL }\end{array}$ & [69] \\
\hline miR-3676 or ts- 53 & $\begin{array}{l}\text { downregulated in all CLLs vs. controls } \\
\text { and co-deleted with TP53 in 17p CLL }\end{array}$ & $\begin{array}{l}\text { belongs to the tRNA-derived small } \\
\text { RNA family (tsRNAs), a new family of } \\
\text { cancer biomarkers }\end{array}$ & {$[24,26]$} \\
\hline $\mathrm{miR}-368$ & overexpressed in $\mathrm{t}(15 ; 17)$ AMLs & & [56] \\
\hline $\operatorname{miR}-374$ & higher in DC56+T-ALL & & [62] \\
\hline $\operatorname{miR}-382$ & overexpressed in $\mathrm{t}(15 ; 17)$ AMLs & & [56] \\
\hline miR- 4521 or ts -101 & $\begin{array}{l}\text { downregulated in all CLLs vs. controls } \\
\text { and co-deleted with TP53 in 17p CLL }\end{array}$ & $\begin{array}{l}\text { belongs to the tRNA-derived small } \\
\text { RNA family (tsRNAs), a new family of } \\
\text { cancer biomarkers }\end{array}$ & {$[24,26]$} \\
\hline miR-99a & $\begin{array}{l}\text { lower expression is associated with } \\
\text { poor prognosis and shorter survival } \\
\text { in ALL }\end{array}$ & ALL staging & {$[41]$} \\
\hline
\end{tabular}

This story begins in early 2000, when our group initiated a research project aimed to identify the tumor suppressor gene targeted by the most common genomic aberration in CLL, deletion of the short arm of chromosome 13 [15]. At that time, deletions of the $11 \mathrm{q}$ region were known to target the ATM gene [70,71], while deletions of the $17 p$ region were known to encompass the p53 gene [72,73]. These aberrations, often found in association with the deletion of $13 q$, were recognized predictors of aggressive disease [74]. However, as opposed to the $11 \mathrm{q}$ and $17 \mathrm{p}$ abnormalities, the $13 \mathrm{q}$ deletion did not seem to affect a coding gene. Large deletions of the $13 q$ chromosome were common and found in at least $50 \%$ of CLL cases either as a sole abnormality or in combination with other aberrations [35]. Interestingly, patients where $13 q$ was the sole chromosomal abnormality usually showed an indolent disease [35]. In 2002, after extensive analysis, our group provided the first evidence that a non-coding small RNA, known as $m i R-15 a / 16-1$, was the functional target of the 13q14 deletion in CLL [15]. This discovery led our group to investigate miR-15a/16-1's role in CLL, and in 2005, we demonstrated that $m i R-15 a / 16-1$ has tumor suppressor functions and can induce apoptosis by targeting the B cell lymphoma 2 (BCL2) gene, a potent inhibitor of the 
apoptotic program [17]. Additionally, we verified that the expressions of $m i R-15 a / 16-1$ and $\mathrm{Bcl} 2$ in CLL samples from patients are inversely correlated [17]. Furthermore, microarray experiments where samples from CLL patients with high vs. low levels of $m i R-15 a / 16-1$ were compared led to the identification of a gene signature containing MCL1, another antiapoptotic BCL2 family member associated with B-CLL cell survival and chemotherapy resistance [75]. These remarkable discoveries revealed that alterations in non-coding genes can lead to malignant transformation of cells, overruling the previous scientific dogma that only protein-coding genes are involved in cancer pathogenesis [76]. Remarkably, in addition to the fact that half of newly diagnosed CLL patients carry a large deletion of the short arm of chromosome 13, mutations, microdeletions and other factors such as allele-specific transcription mechanisms also regulate the expression of miR-15a/16-1 in most CLL patients [16,77]. As a result, about $90 \%$ of CLLs show a deficit of $m i R-15 a / 16-1$ expression, indicating that the loss of regulation upon the apoptotic mechanism mediated by miR-15a/16-1 is, in fact, the driver event leading to CLL onset [52]. This discovery was a key element in the design of the Bcl2 inhibitor venetoclax, which was approved by the FDA in 2016 for the treatment of aggressive CLLs [39]. Importantly, our group recently showed that in addition to BCL2, miR-15a/16-1 also targets ROR1, an embryonic oncoprotein that, in postpartum tissues, is only expressed on the membrane of cancer cells [52]. Thus, we tested a humanized anti-ROR1 antibody, cirmtuzumab, to evaluate its effectiveness when used in combination with venetoclax [52]. We found that cirmtuzumab enhances the in vitro cytotoxic activity of venetoclcax for CLL cells with a high-level expression of ROR1, indicating that combining these drugs may have a synergistic effect in CLL patients, by simultaneously targeting ROR1 and Bcl2 in the same leukemic cells [52]. Such a treatment strategy is exceptionally valuable because it targets two driver genes that, within the same cancer cell, are overexpressed as a consequence of the same deficit, i.e., the loss of $m i R-15 a / 16-1$, thus preventing the possibility of selecting a resistant clone [52]. In addition, we investigated the interactions between $m i R-15 a / 16-1$ and other chromosomal alterations observed in CLL, to evaluate what miRNA-mediated molecular pathway could explain the prognostic implications of 11q, 17p and 13q deletions in CLL [69]. Interestingly, the $11 q$ deleted region includes the $m i R-34 b / c$ cluster locus. Binding sites for p53 were found upstream the miR-15a/16-1 locus on chromosome 13, and upstream the $m i R-34 b / c$ locus on chromosome 11 [69]. In 2011, we published a study showing that p53 induces the expression of $m i R-15 a / 16-1$ and $m i R-34 b / c$, while $m i R-15 a / 16-1$ targets $T P 53$, and $m i R-34 b / c$ targets $Z A P-70$, an indicator of an unfavorable prognosis [69]. Thus, in patients with $13 q$ deletion as a sole abnormality, the loss of $m i R-15 a / 16-1$ expression leads to higher levels of pro-apoptotic p53, explaining the association of 13q- with indolent disease. Indeed, in this scenario, the number of apoptotic cells decreases because of the higher level of $\mathrm{Bcl} 2$, but the intact p53 pathway keeps the tumor growth relatively low and leads to transactivation of $m i R-34 b / c$, with a consequent low ZAP-70 level [69] (Figure 1A,B). In CLL patients with 11q deletion, since miR-15a/16-1 is not deleted, TP53 is not upregulated. In this scenario, lower control on apoptosis is provided, explaining the more aggressive presentation. Furthermore, p53-driven transactivation of $m i R-34 b / c$ is ineffective, since this miRNA is deleted, leading to a higher expression of ZAP-70 [69] (Figure 1C). Lastly, deletion of 17p and TP53 mutations highly correlates with poor outcomes and response to treatment [78] (Figure 1D). However, more than half of the refractory cases cannot be explained by the lack of p53 expression alone [79]. A study carried out by Zenz et al. showed that $m i R-34 a$ expression is lower in chemotherapy-resistant CLL regardless of the 17p deletion/TP53 mutation [66]. Thus, in addition to $m i R-15 a / 16-1$, other miRNAs have a role in CLL development and progression, such as the $m i R-34 b / c$ cluster and $m i R-34 a$. Interestingly, we found $m i R-34 a$ to be downregulated in CLL patients that undergo Richter transformation, a rare but serious complication that affects about 5\% of CLL patients and is characterized by the sudden development of an aggressive large diffuse B cell lymphoma with a poor prognosis [42]. We established that downregulation of $m i R-34 a$ and overexpression of $m i R-125 a$ can predict the transformation to lymphoma in more 
than $50 \%$ of CLL patients up to 5 years prior, with a false positive rate of less than $10 \%$. This is a significant discovery because no marker is currently available to assign a risk factor for Richter transformation to patients [42] (Figure 1E). Since several microarray experiments revealed miRNA signatures in CLL $[25,80]$, we studied the dysregulation of several other miRNAs in CLL onset, progression and resistance development. Among the most dysregulated miRNAs, the expression of $m i R-181 b$ was investigated by Visone et al., in the progression from a clinically indolent disease to a more aggressive form [61]. In this study, we showed that, when compared to normal B cells, $m i R-181 b$ is downregulated in CLL cells form both indolent and aggressive cases, and that miR-181b expression diminishes while the disease progresses from an indolent to an aggressive stage. This significant discovery suggests that $m i R-181 b$ could be used as a biomarker to track disease progression and, potentially, as a treatment agent to reduce expansion of B-CLL leukemic cells $[81,82]$. As opposed to miR-181, miR-29 was found overexpressed in CLL cells from both indolent and aggressive cases when compared to normal B cells [63]. However, similar to miR-181b, indolent cases show a higher expression than aggressive cases [16]. Interestingly, both miR$181 \mathrm{~b}$ and miR-29 regulate the expression of the T cell leukemia 1A gene, TCL1A, which is highly expressed in patients with aggressive disease, suggesting that their downregulation may contribute to disease staging by driving the overexpression of Tcl1 [18] (Figure 1E). Since TCL1 overexpression is a contributing event in the pathogenesis of the aggressive form of CLL, we sought to identify other miRNAs targeting TCL1 that could play a role in the development and progression of CLL. We found that miR-3676 targets a region of the $3^{\prime}$ UTR of TCL1 containing three consecutive 28 bp repeats [24]. While studying miR-3676, we realized that it is embedded in a tRNA sequence. Further analysis showed that miR-3676 is a tRNA-derived small RNA (tsRNAs), and we re-named this molecule ts-53 [26]. tsRNAs are single-stranded unique sequences of 16-48 nucleotides ending with a stretch of 3 or more Ts and produced in the nucleus as a consequence of the $3^{\prime}$-end cut of a tRNA precursor performed by the enzyme RNase Z [83]. We demonstrated that ts-53 and its neighbor $t s-101$ (previously known as miR-3676 and miR-4521, respectively) interact with both Ago and Piwi proteins; thus, they could act both as miRNAs (which function as post-transcriptional silencers of target genes) or as piRNAs (which function as epigenetic silencers of transposons and other genetic elements) [23]. Since the genes codifying for these tsRNAs are located in tandem within the region of chromosome 17 that is deleted in 17p- CLL, ts-53 is co-deleted with TP53 in 17p- CLL cells [24]. In addition, we found that $t s-53$ is also downregulated in all CLL groups [24,84]. Remarkably, ts-53 targets the $3^{\prime}$ UTR of TCL1, and its downregulation in CLL is inversely correlated with TCL1 expression, suggesting that tsRNAs can control gene expression post-transcriptionally [24]. Additionally, the ts-53 and $t s-101$ expression pattern is positively correlated with ZAP-70 methylation, and the ts-101 sequence shows a complementarity of 13 out of 14 bases to the ZAP-70 promoter region [23]. This evidence supports the hypothesis that tsRNAs could interfere with the epigenetic regulation of genes by providing sequence specificity for the Piwi-ribonucleoprotein complexes to interact with the promoter of the target gene [85]. Thus, similar to our previous work on $m i R-15 a / 16-1$ located at $13 q$, we demonstrated that ts-53 can be inactivated in CLL by several mechanisms such as deletions, mutations and processing defects. These data show that small non-coding RNAs of different types can affect the onset and progression of CLL and possibly other cancers and may represent valuable diagnostic tools and targets for therapy $[85,86]$.

\section{2. $m i R N A s$ in $A L L$}

Acute lymphocytic leukemia (ALL) is the most common type of childhood leukemia, developing from B or T cells at different stages of maturity [4,87]. ALL also affects adults, with a significantly poorer response to treatment and survival [88,89]. In 2008, the World Health Organization classified ALL into two major groups, based on lineage: B lymphoblastic and T lymphoblastic leukemia. In addition, B lymphoblastic leukemia is divided into two subtypes: B-ALL with recurrent genetic abnormalities and B-ALL not otherwise speci- 
fied. B-ALL with recurrent genetic abnormalities is further delineated based on specific chromosomal rearrangements [90]. B cell ALL accounts for $~ 75 \%$ of cases, while T cell ALL constitutes the remaining cases [91].
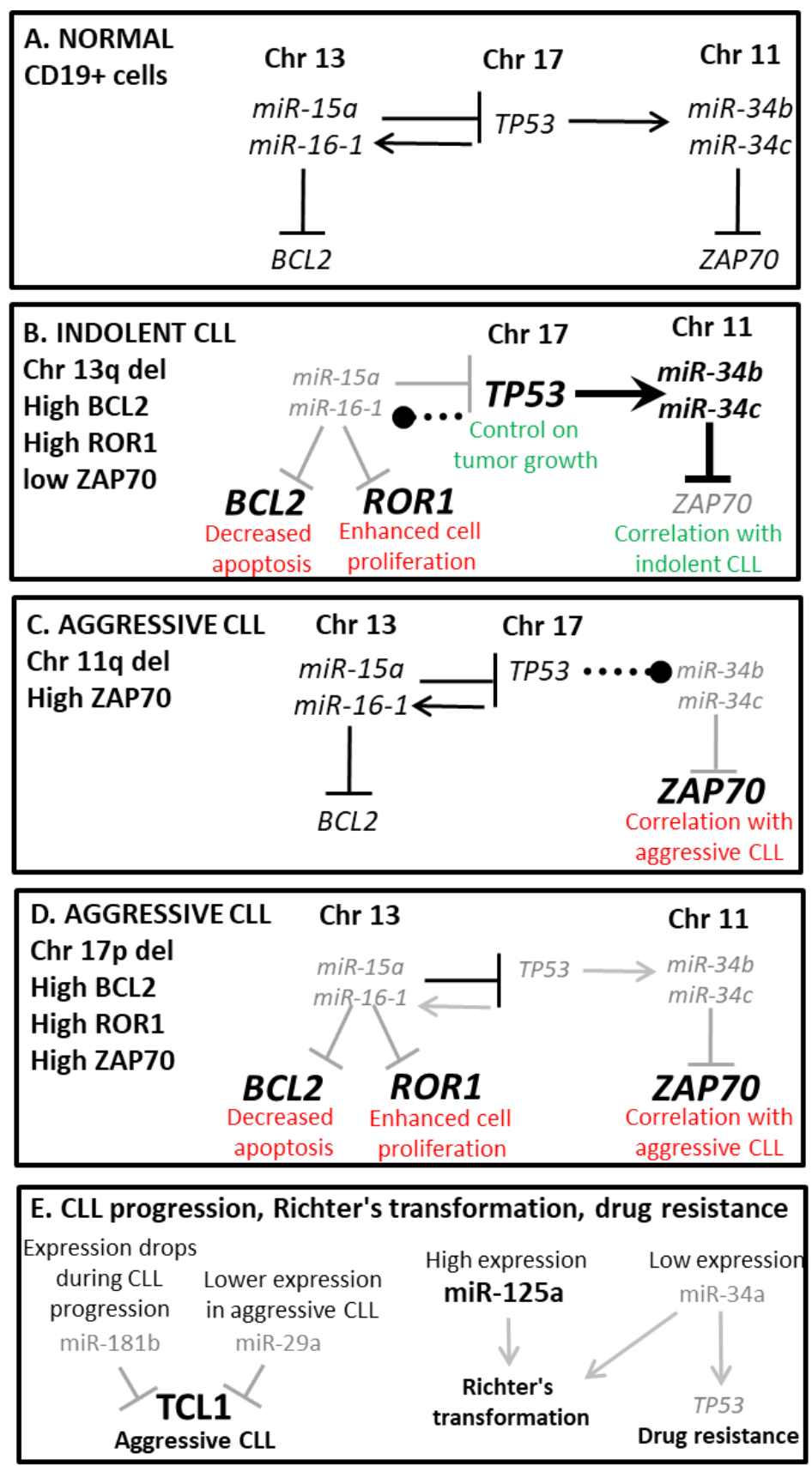

Figure 1. Interplay between microRNA expression and chromosomal aberration in CLL.

In 2009, Schotte et al. cloned 105 known and 8 new miRNA genes expressed in B-ALL and T-ALL. This study revealed ALL subtype-specific miRNA profiles [92]. Indeed, this report shows that the expression of miRNA genes varies in different subtypes of pediatric ALL and normal CD34b progenitor cells and suggests that the differential expression of specific miRNAs, such as $m i R-196 b$ and $m i R-708$, is more associated with the leukemic subtype than with the maturation status of cells [92]. In addition, miRNA expression profiling can discriminate childhood T- from B-acute lymphoblastic leukemia [93] and cluster acute leukemia samples into three groups corresponding to specific chromosomal rearrangements: (i) $B C R-A B L$, a hallmark of CML also found in high-risk ALL; (ii) $\mathrm{t}(12 ; 21)(\mathrm{p} 13 ; \mathrm{q} 22)$, 
also known as ETV6/RUNX1 or TEL-AML1 translocation, which is associated with a good outcome; and (iii) MLL1 disruption on chromosome 11q23, which correlates with a poor outcome [94-97]. Thus, miRNA patterns can distinguish B-lineage from T-lineage ALL and classify ALL of different cytogenetic groups. In 2012, de Oliveira et al. noted that leukemic blasts showed lower expression levels of $m i R-100, m i R-196 b$ and let-7e when compared to normal bone marrow cells (BMCs) [40]. Conversely, when clustering patients according to their biological features, an increased expression of miR-100 appeared associated with the $t(12 ; 21)$ translocation. This observation suggests the possibility of a $t(12 ; 21)$-specific regulation of miR-100 [40] in ETV6/RUNX1 ALL, which shows better prognostic outcomes when compared to the other groups. Shortly after, Li et al. showed that lower expressions of $m i R-100$ and $m i R-99 a$ are associated with a poor prognosis and shorter survival in ALL. Moreover, this report shows that these miRs inhibit the expression of IGF1R and $m$ TOR and their downstream oncogene MCL1 [41]. In 2015, Yang et al. [52] identified miR-181a as the most significantly downregulated miRNA in the peripheral blood of childhood ALL patients with the $t(12 ; 21)$ translocation compared to precursor B-ALL [57]. This report shows that miR-181a and ETV6/RUNX1 regulate each other. Thus, a double negative loop involving miR-181a may contribute to the ETV6/RUNX1-driven arrest of differentiation in pre-B ALL and suggests that miR-181a is a lost tumor suppressor in ALL [58]. In support of this hypothesis, in 2017, Nabhan et al. noted a decrease in the expression level of miR-181a in the serum of children diagnosed with ALL [59]. Conversely, Verducci et al. proposed that miR-181a is an onco-miRNA in ALL, and that its biological effects are mediated by EGR1 in Jurkat cell line models [98]. Shortly after, Haque et al. suggested that miR-181a could be an assimilated oncomiR in ALL via exosome-mediated uptake [60]. Since exosomes from patients showed overexpression of miR-181a when compared to exosomes from healthy donor controls, in this study, exosomes isolated from the serum of ALL patients were used to condition the medium of leukemic B cell lines. This conditioning promoted cell proliferation of leukemic cell lines by suppressing pro-apoptotic genes such as $B A D$ and $B A X$ and by upregulating proliferative and pro-survival genes such as PCNA, Ki-67, $M C L-1$ and BCL2 [60]. In addition, the authors carried out silencing of exosomal miR-181a using an $m i R-181 a$ inhibitor and confirmed that $m i R-181 a$ inhibitor treatment reverses the exosome-induced leukemic cell proliferation in vitro [60]. Altogether, these results indicate that miR-181 is involved in ALL, but it is still unclear whether its role is that of a tumor suppressor or an oncomiR. Other studies showed additional dysregulated miRNAs in ALL. In 2013, Gimenes-Teixeira found that $m i R-221$ and $m i R-374$ were expressed at significantly higher levels in CD56+ T-ALL than in CD56- T-ALL, and in leukemic blasts compared to normal thymocytes and normal T cells. In addition, high expression of miR-221 was associated with a poorer prognosis [62]. In 2018, Swellam et al. investigated the expression signature of $m i R-125 b-1$ and $m i R-203$ among childhood ALL cases and proposed these miRNAs as molecular markers for the diagnosis of childhood ALL. They noticed that when compared to control samples, newly diagnosed children with ALL show a significantly higher expression level of $m i R-125 b-1$ and a significantly lower expression level of $m i R-$ 203 [43]. Moreover, miR-125-1 was increased in T-ALL compared to other ALLs. Thus, miRNAs are involved in ALL development and staging and could represent excellent diagnostic tools or targets for therapy.

\section{3. miRNA Signatures in AML}

Acute myeloid leukemia is the most common acute leukemia in adults and is characterized by the abnormal proliferation of myeloid stem cells [99]. AML often evolves from myelodysplastic syndromes (MDSs), a very heterogeneous group of myeloid disorders [100]. Cytogenetic and molecular findings provided a model of stepwise genetic progression that may explain the development and evolution of MDSs to AML [101]. However, while the classification for AML is based on cytogenetic and genetic abnormalities, the classification for MDSs / AML still relies on morphological findings [102]. Genetic mutations are identified in more than $97 \%$ of AML cases [103], and cytogenetic abnormalities 
are detected in $50 \%$ to $60 \%$ of newly diagnosed AML cases [104,105]. Specifically, t(8:21) translocations resulting in the formation of the chimeric protein RUNX1-RUNX1T1 are generally associated with a favorable prognosis. However, a high frequency of relapse is observed in pediatric cases showing a specific epigenetic signature [106]. Rearrangements of chromosome 11 involving the $M L L$ gene are more common in pediatric cases and are associated with an intermediate prognosis [107]. The $t(15 ; 17)$ translocation, resulting in the expression of the PML-RAR $\alpha$ oncoprotein, is found in almost all acute promyelocytic leukemias (APLs), a very aggressive subtype of AML [108].

Following the data obtained from microarray experiments carried out on AML samples from patients, miRNA dysregulation was shown in AML. A specific signature of $26 \mathrm{miR}-$ NAs was identified in AML, associating with specific AML karyotype subgroups [109]. Shortly after, $m i R-224, m i R-368$ and $m i R-382$ were found almost exclusively overexpressed in $\mathrm{t}(15 ; 17)$ AMLs, whereas the miR-17-92 cluster was found overexpressed in patients with MLL rearrangements [56]. Dysregulation and mutations of miR-29 family members were also reported to play a role in AML progression and pathogenesis [64,65]. In addition, miR-29b targets DNA methyltransferase including DNMT3A, DNMT3B and Sp1 (a transcriptional regulator of $D N M T 1$ ) [110]. Thus, downregulation of $m i R-29 b$ promotes DNA hypermethylation and gene silencing. In addition, $m i R-29 a$ and $m i R-29 b$ alter the expression of genes involved in apoptosis, cell cycle progression and cellular proliferation, by affecting the AKT pathway and the phosphorylation of Rb. The study which reported such a finding suggested that $m i R-29 a$ and $m i R-29 b$ may be considered as therapeutic targets in AML [111]. The expression of miR-34 cluster members was also studied in AML. In 2010, Pulikkan et al. showed that miR-34a blocks myeloid proliferation by targeting E2F3 during granulopoiesis, but it is downregulated in AML with mutations affecting the CCAAT enhancer binding protein alpha $(C / E B P \alpha) . C / E B P \alpha$ is a myeloid tumor suppressor and a key regulator of granulopoiesis. Importantly, $C / E B P \alpha$ directly regulates $m i R-34 a$ during granulopoiesis. Thus, in AML where C/EBP $\alpha$ function is lost, $m i R-34 a$ is blocked, leading to $E 2 F 3$ upregulation, which results in increased proliferation of myeloid progenitors [112]. Interestingly, another study reported that in complex karyotype AML, the role of miR-34a in clinical prognosis is influenced by the status of p53. Indeed, in complex karyotype AML patients with functional TP53, upregulation of $m i R-34 a$ associates with shorter overall survival, whereas in patients with impaired TP53, it associates with longer overall survival and chemotherapy sensitivity [67]. Interestingly, no direct correlation between p53 pathway genes and $m i R-34$ a expression was found, suggesting that the induction of $m i R-34 a$ may be p53 independent [67]. MiR-181 was also evaluated in AML, and its overexpression was positively associated with a good clinical outcome [68,113]. Interestingly, miR-181 family members were found upregulated in patients with $C / E B P \alpha$ mutations, as opposed to $m i R-34 a$. This observation suggests that microRNAs have a complex effect on the myeloid differentiation pathway [114]. In cytogenetically normal AML patients, miR-181 contributed to a better clinical outcome by regulating Toll-like receptors and interleukin-1 $\beta$, while in cytogenetically abnormal AML, miR-181 contributed to a better clinical outcome by regulating HOXA7, HOXA9, HOXA11 and PBX3 [115]. Moreover, miR-181b can increase AML drug sensitivity through downregulation of $H M G B 1$ and $M C L-1$, and it is indeed downregulated in relapsed and refractory AML patients [116]. Recently, our group discovered that miR-15/16 genes have an important role in AML development [53]. A member of the $m i R-15 / 16$ family (miR-15b/16-2 cluster) is located at 3q25 and is almost identical to $m i R-15 a / 16-1$. Since the tumor suppressor function of the $m i R-15 a / 16-1$ cluster was well established in CLL, we sought to determine whether miR-15b/16-2 could have a role in cancer and generated miR-15b/16-2 knockout mice [54]. Interestingly, we noted that by the age of 15-18 months, miR-15b/16-2 KO mice developed a CD5+ B cell proliferation similar to human CLL, with a penetrance of $60 \%$. However, the expression of BCL2 was found to be only mildly upregulated, whereas a robust upregulation of Cyclin D1 and Cyclin D2, which are predicted targets of miR-15/16, was revealed [54]. Following these exciting results, we decided to study the effect of the combined loss of both loci and generated a 
double KO mouse model by crossbreeding miR-15a/16-1 and miR-15b/16-2 KO mice [55]. Surprisingly, the deletion of both clusters promoted myeloproliferative disorders in the majority of the mice by the age of 5 months, suggesting that a fraction of AML could be caused by the loss of both miR-15/16 clusters [55] (Figure 2). In addition, we observed a striking upregulation of Cyclin D1, Cyclin D2 and Bcl-2 [55]. These astonishing results led us to compare the expression of the two miR-15/16 clusters in patients with myelodysplastic syndrome (MDS) and AML patients [53]. We discovered that reduced expression of $m i R-$ $15 a, m i R-15 b$ and $m i R-16$ can predict the progression from MDS to AML, thus suggesting that the expression of these two $m i R-15 / 16$ clusters can be a valuable marker to stratify AML patients for therapy [53]. Moreover, we discovered that, while $\sim 79 \%$ of AML patients show a downregulation of either $m i R-15 a / 16-1$ or $m i R-15 b / 16-2, \sim 21 \%$ of patients show a downregulation of both, suggesting that loss of expression of both $m i R-15 a / 16-1$ and miR-15b/16-2 is a common event in AML [53]. Thus, the fraction of AML cases that lost the expression of miR-15/16 should be treated with venetoclax, alone or in combination with anti-ROR1 monoclonal antibodies. Treatment with venetoclax should also be considered to prevent the transition of MDS to AML. Indeed, venetoclax has very mild side effects and shows remarkable activity in AML.

miR15a KO

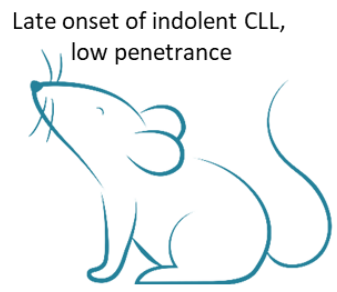

miR15b KO

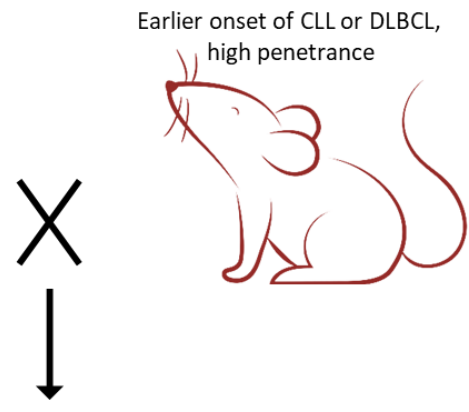

miR15a KO - miR15b KO

Early onset of AML or DLBCL

high penetrance

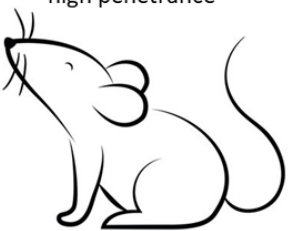

Figure 2. Double KO mice, lacking both miR15a and miR-15b, develop AML.

\section{4. miRNA Signatures in CML}

Chronic myeloid leukemia (CML) was the first human malignancy to be associated with a chromosomal rearrangement: a translocation involving chromosomes $9 \mathrm{q} 34$ and 22q11 [117]. This rearrangement generates the Philadelphia chromosome, encoding for the brc-abl oncoprotein. brc-abl is an active tyrosine kinase that promotes cell growth and replication and is the main driver of CML pathogenesis [118,119]. The natural course of CML begins with a chronic phase (CP) that progresses through an accelerated phase (AP) to the blast crisis (BC) phase [120], a major challenge in the management of CML. The progression to $\mathrm{BC}$ is the consequence of continued $B C R-A B L$ activity leading to genetic instability, DNA damage and impaired DNA repair [121]. Importantly, the discovery of the Philadelphia chromosome, and the brc-abl oncoprotein, led to the development of the first signal transduction inhibitor (STI) used in a clinical setting, imatinib, a drug designed to directly bind the brc-abl oncoprotein and inhibit its oncogenic activity [122,123]. The introduction of such a drug significantly improved the treatment outcome of CML as brc-abl expression can be reduced by imatinib to very low or nondetectable levels in the majority of patients [124]. However, a variety of mutations are associated with progression 
to $\mathrm{BC}$, and such mutations in late $\mathrm{CP}$ often lead to imatinib resistance. Despite major clinical advances, imatinib resistance is a challenging problem in the management of CML [125]. miRNAs have been demonstrated to play a critical role in the pathogenesis of CML [126]. Indeed, miRNA signatures were described to discriminate CML cells from normal cells [127], to identify responder and non-responder patients [128] and to define clinical phases of CML [45]. In addition, while miRNAs can target and regulate the expression of $B C R-$ $A B L[46,47]$, brc-abl can regulate the expression of miRNAs [48]. In 2008, miR-203 was found hypermethylated in CML. This study showed that miR-203 targets ABL1 and the bcrabl fusion protein, thus preventing tumor cell proliferation. Hence, miR-203 may function as a tumor suppressor, and restoration of its expression might have therapeutic benefits in CML [49]. In 2018, a BCR-ABL loop involving MYC and $m i R-150$ was described showing that bcr-abl inhibits miR-150 expression in CML cells via the transcriptional activation of $M Y C$ and its simultaneous recruitment to a specific locus of the miR-150 gene, where myc binds and acts as a direct repressor of $m i R-150$ transcription [50]. Most Philadelphia chromosome-positive CMLs are treated with bcr-abl kinase inhibitors such as imatinib or dasatinib, or other tyrosine kinase inhibitors (TKIs) that prevent the interaction between bcr-abl and ATP. Nevertheless, $2 \%$ of patients become resistant to TKIs, and in such cases, allogeneic hematopoietic stem cell transplantation (allo-HSCT) is the only curative treatment for CML [51]. For these reasons, several studies were carried out and found that the dysregulation of miRs and their predicted target genes is different in CML phases and after treatment with TK inhibitors [128]. Indeed, imatinib treatment leads to increased expression of $m i R-150$ and $m i R-146 a$, and reduced expression of $m i R-142-3 p$ and $m i R-199 b$ $5 p$ [44]. Interestingly, both $m i R-150$ and $m i R-146 a$ are regulated by BCR-ABL1 [48,50], and $m i R-150$ may be a useful biomarker for disease progression, where its lower expression correlates with a poor prognosis and more advanced phases of CML [44,45]. Altogether, these studies suggest that TKI may be able to restore the levels of some miRNAs, and that this process may have a role in mediating the effect of TKIs on CML survival and apoptosis.

In addition to TKI resistance, another important event that may be associated with miRNA dysregulation in CML is the transition from the chronic phase to blast crisis. The development of $\mathrm{BC}$ is the consequence of sustained $B C R-A B L$ activity [120], which leads to genomic instability and DNA damage [120]. However, the molecular mechanisms responsible for this process are not fully understood. Since we previously showed that loss of $m i R-15 / 16$ loci is a key event in the development of AML [55] and CLL [15], we evaluated the correlation between the expression of $m i R-15 a / 16$ and the transition of CML from the chronic phase to the blastic phase [129]. We collected samples from patients in the $\mathrm{CP}$, samples from patients in $\mathrm{BC}$ and sequential samples from patients where the first set was obtained during the $\mathrm{CP}$ and the second set during $\mathrm{BC}$. We found that CMLs in the CP express less $m i R-15 a, m i R-15 b$ and $m i R-16$ than normal CD34+, and that CMLs in BC express less $m i R-15 \mathrm{a}, m i R-15 \mathrm{~b}$ and $m i R-16$ than CMLs in the CP. Thus, we analyzed paired samples collected from the same patients during the chronic phase and blast crisis and found a significant decrease in the expression of all these miRs during the progression of the disease. In addition, we observed a significant overexpression of their targets, Bmi-1, ROR1 and Bcl-2. Thus, loss of both miR-15/16 clusters is a driving event in the transition from the chronic phase to blast crisis [129]. CML progression from the CP to BC is likely mediated by a progressive downregulation of $m i R-15 / 16$, resulting in the overexpression of $\mathrm{Bcl}-2$, ROR1 and Bmi-1. Therefore, as for CLL, targeting different oncogenes activated by the same genetic/epigenetic alteration may be a more successful treatment approach, with the considerable advantage of tackling the problem of resistance development [129].

\section{Conclusions}

The study of small non-coding RNAs has extraordinary implications in the management of cancer patients. The identification of new markers for differential diagnosis can improve the stratification of patient for the most effective treatment. In addition, small non-coding RNAs can be exploited to monitor disease progression and drug re- 
sistance onset. The study of small non-coding RNAs is also crucial for the discovery of new targets for therapy. Indeed, the development of novel drugs to use in combination for synergistic effects is essential for the design of therapeutic strategies that can prevent drug resistance onset. While investigating the role of genetic abnormalities in CLL, our group revealed that miR-15a/16-1 is lost in CLL [15], and that these molecules regulate the apoptotic process by targeting Bcl2 [17]. This observation led to the groundbreaking discovery that microRNAs have a key role in the fine-tuning of gene expression and affect cell survival and apoptosis. The identification of the BCL2 translocation in 1984 [130] and the description of the miR-15a/16-1-mediated post-transcriptional mechanism of regulation of Bcl2 in 2005 [17] were fundamental steps for the development of one of the most effective drugs for the treatment of CLL, venetoclax. In addition, we found that miR-15a/16-1 targets ROR1, an onco-embryonic surface protein expressed on CLL cells but not on normal cells [21]. The anti-ROR1 monoclonal antibody cirmtuzumab is currently being evaluated for treatment, and we showed that it has a synergistic effect with the in vitro cytotoxic activity of venetoclcax [21]. Remarkably, miR-15a/16-1 is often downregulated in other hematopoietic malignancies and cancers of different types. Indeed, most AML patients show a downregulation of either $m i R-15 a / 16-1$ or $m i R-15 b / 16-2$, and $\sim 21 \%$ of AML patients show a downregulation of both [53]. These AML patients should be considered for treatment with venetoclax, alone or in combination with cirmtuzumab. We also found a correlation between the expression of miR-15a/16 and the transition of CML from the chronic phase to the blastic phase [129], showing that the expression of these miRs decreases during the progression of the disease, while their targets are overexpressed. Thus, loss of both miR-15/16 clusters is a driving event in the transition from the chronic phase to blast crisis, and CML patients should also be considered for combination therapy with venetoclax and cirmtuzumab. Other microRNAs have been found dysregulated in leukemia of different types and represent markers for disease classification, progression and treatment response. For instance, the miR-181 family members are dysregulated in several types of leukemia. Downregulation of $m i R-181 b$ is a potent indicator of disease progression in CLL patients [61], and $m i R-181 \mathrm{~b}$ has been studied as a possible therapeutic agent for CLL [82]. In addition, the same microRNA is downregulated in relapsed and refractory AML patients [116]. miR-181a seems to be involved in ALL; however, it is still unclear whether its role is that of a tumor suppressor or an oncomiR $[57,60]$. These studies suggest that dysregulation of miR-181 family members may be exploited for the development of diagnostic tools and therapy. Downregulation of miR-34a and upregulation of miR-125a can predict Richter's transformation of CLL [42], and signatures of microRNAs have been detected in ALL discriminating lineages and cytogenetic groups [93,96]. In addition, feedback loops have been identified between microRNA genes and protein-coding genes: TP53 transactivates $m i R-15 a / 16-1$ and $m i R-34 b / c$ in CLL [69], and MYC binds and directly inhibits miR-150 transcription in CML [50]. The study of microRNAs in cancer has greatly improved our understanding of cancer pathogenesis and opened new possibilities for the development of superior diagnostic tools and targets for therapy. In addition, we have discovered that other small non-coding RNAs are dysregulated in cancer, such as tRNA-derived small RNAs, tsRNAs [23]. The dysregulation of these molecules and their role in the fine-tuning of genes can also be exploited to improve the array of diagnostic tools for accurate differential diagnosis, and to provide new targets for the development of more specific anticancer drugs. In conclusion, the study of small non-coding RNAs has greatly improved our understanding of cancer pathogenesis and opened new possibilities for the development of superior diagnostic tools and targets for therapy. Small non-coding RNAs are key regulators of gene expression, and the study of their role in cancer onset, progression, relapse and resistance to therapy is essential to improve the stratification of patients for successful treatment, and to lay the groundwork for the design of the next generation of anticancer drugs. 


\begin{abstract}
Author Contributions: Writing—original draft preparation, V.B.; writing—review and editing V.B. and C.M.C. All authors have read and agreed to the published version of the manuscript.
\end{abstract}

Funding: This research received no external funding.

Conflicts of Interest: The authors declare no conflict of interest.

\title{
References
}

1. Preisler, H.D. The leukemias. Dis. Mon. 1994, 40, 525-579. [CrossRef]

2. Scarfò, L.; Ferreri, A.J.; Ghia, P. Chronic lymphocytic leukaemia. Crit. Rev. Oncol. Hematol. 2016, 104, 169-182. [CrossRef] [PubMed]

3. Onciu, M. Acute lymphoblastic leukemia. Hematol. Oncol. Clin. N. Am. 2009, 23, 655-674. [CrossRef] [PubMed]

4. Hunger, S.P.; Mullighan, C.G. Acute Lymphoblastic Leukemia in Children. N. Engl. J. Med. 2015, 373, 1541-1552. [CrossRef]

5. Saultz, J.N.; Garzon, R. Acute Myeloid Leukemia: A Concise Review. J. Clin. Med. 2016, 5, 33. [CrossRef] [PubMed]

6. Faderl, S.; Talpaz, M.; Estrov, Z.; O’Brien, S.; Kurzrock, R.; Kantarjian, H.M. The biology of chronic myeloid leukemia. N. Engl. J. Med. 1999, 341, 164-172. [CrossRef] [PubMed]

7. Taylor, J.; Xiao, W.; Abdel-Wahab, O. Diagnosis and classification of hematologic malignancies on the basis of genetics. Blood 2017, 130, 410-423. [CrossRef] [PubMed]

8. Kelly, L.; Clark, J.; Gilliland, D.G. Comprehensive genotypic analysis of leukemia: Clinical and therapeutic implications. Curr. Opin Oncol. 2002, 14, 10-18. [CrossRef]

9. Nowell, P.C.; Croce, C.M. Chromosomal approaches to the molecular basis of neoplasia. Symp. Fundam Cancer Res. 1986, 39, $17-29$.

10. Rowley, J.D. Biological implications of consistent chromosome rearrangements in leukemia and lymphoma. Cancer Res. 1984, 44, 3159-3168.

11. Nowell, P.; Hungerford, D. A minute chromosome in human chronic granulocytic leukemia. Landmarks Med. Genet. Class. Pap. Comment. 1960, 132, 1497.

12. Garofalo, M.; Quintavalle, C.; Zanca, C.; De Rienzo, A.; Romano, G.; Acunzo, M.; Puca, L.; Incoronato, M.; Croce, C.M.; Condorelli, G. Akt regulates drug-induced cell death through Bcl-w downregulation. PLoS ONE 2008, 3, e4070. [CrossRef] [PubMed]

13. Haldar, S.; Jena, N.; Croce, C.M. Inactivation of Bcl-2 by phosphorylation. Proc. Natl. Acad. Sci. USA 1995, 92, $4507-4511$. [CrossRef]

14. Croce, C.M.; Reed, J.C. Finally, An Apoptosis-Targeting Therapeutic for Cancer. Cancer Res. 2016, 76, 5914-5920. [CrossRef] [PubMed]

15. Calin, G.A.; Dumitru, C.D.; Shimizu, M.; Bichi, R.; Zupo, S.; Noch, E.; Aldler, H.; Rattan, S.; Keating, M.; Rai, K.; et al. Frequent deletions and down-regulation of micro- RNA genes miR15 and miR16 at 13q14 in chronic lymphocytic leukemia. Proc. Natl. Acad. Sci. USA 2002, 99, 15524-15529. [CrossRef]

16. Calin, G.A.; Ferracin, M.; Cimmino, A.; Di Leva, G.; Shimizu, M.; Wojcik, S.E.; Iorio, M.V.; Visone, R.; Sever, N.I.; Fabbri, M.; et al. A MicroRNA signature associated with prognosis and progression in chronic lymphocytic leukemia. N. Engl. J. Med. 2005, 353, 1793-1801. [CrossRef] [PubMed]

17. Cimmino, A.; Calin, G.A.; Fabbri, M.; Iorio, M.V.; Ferracin, M.; Shimizu, M.; Wojcik, S.E.; Aqeilan, R.I.; Zupo, S.; Dono, M.; et al miR-15 and miR-16 induce apoptosis by targeting BCL2. Proc. Natl. Acad. Sci. USA 2005, 102, 13944-13949. [CrossRef]

18. Pekarsky, Y.; Santanam, U.; Cimmino, A.; Palamarchuk, A.; Efanov, A.; Maximov, V.; Volinia, S.; Alder, H.; Liu, C.G.; Rassenti, L.; et al. Tcl1 expression in chronic lymphocytic leukemia is regulated by miR-29 and miR-181. Cancer Res. 2006, 66, 11590-11593. [CrossRef]

19. Calin, G.A.; Croce, C.M. MicroRNA signatures in human cancers. Nat. Rev. Cancer 2006, 6, 857-866. [CrossRef]

20. Aqeilan, R.I.; Calin, G.A.; Croce, C.M. miR-15a and miR-16-1 in cancer: Discovery, function and future perspectives. Cell Death Differ. 2010, 17, 215-220. [CrossRef]

21. Balatti, V.; Croce, C.M. MicroRNA dysregulation and multi-targeted therapy for cancer treatment. Adv. Biol. Regul. 2019, 75, 100669. [CrossRef]

22. Pekarsky, Y.; Croce, C.M. Noncoding RNA genes in cancer pathogenesis. Adv. Biol. Regul. 2019, 71, 219-223. [CrossRef]

23. Pekarsky, Y.; Balatti, V.; Palamarchuk, A.; Rizzotto, L.; Veneziano, D.; Nigita, G.; Rassenti, L.Z.; Pass, H.I.; Kipps, T.J.; Liu, C.G.; et al. Dysregulation of a family of short noncoding RNAs, tsRNAs, in human cancer. Proc. Natl. Acad. Sci. USA 2016, 113, 5071-5076. [CrossRef]

24. Balatti, V.; Rizzotto, L.; Miller, C.; Palamarchuk, A.; Fadda, P.; Pandolfo, R.; Rassenti, L.Z.; Hertlein, E.; Ruppert, A.S.; Lozanski, A.; et al. TCL1 targeting miR-3676 is codeleted with tumor protein p53 in chronic lymphocytic leukemia. Proc. Natl. Acad. Sci. USA 2015, 112, 2169-2174. [CrossRef] [PubMed]

25. Liu, C.G.; Spizzo, R.; Calin, G.A.; Croce, C.M. Expression profiling of microRNA using oligo DNA arrays. Methods 2008, 44, 22-30. [CrossRef] [PubMed]

26. Balatti, V.; Nigita, G.; Veneziano, D.; Drusco, A.; Stein, G.S.; Messier, T.L.; Farina, N.H.; Lian, J.B.; Tomasello, L.; Liu, C.-G.; et al. TsRNA signatures in cancer. Proc. Natl. Acad. Sci. USA 2017, in press. [CrossRef] 
27. Krishnan, P.; Ghosh, S.; Graham, K.; Mackey, J.R.; Kovalchuk, O.; Damaraju, S. Piwi-interacting RNAs and PIWI genes as novel prognostic markers for breast cancer. Oncotarget 2016, 7, 37944-37956. [CrossRef]

28. Esteller, M. Non-coding RNAs in human disease. Nat. Rev. Genet. 2011, 12, 861-874. [CrossRef]

29. Kim, V.N. MicroRNA biogenesis: Coordinated cropping and dicing. Nat. Rev. Mol. Cell Biol. 2005, 6, 376-385. [CrossRef] [PubMed]

30. Winter, J.; Jung, S.; Keller, S.; Gregory, R.I.; Diederichs, S. Many roads to maturity: MicroRNA biogenesis pathways and their regulation. Nat. Cell Biol. 2009, 11, 228-234. [CrossRef]

31. Grimson, A.; Farh, K.K.; Johnston, W.K.; Garrett-Engele, P.; Lim, L.P.; Bartel, D.P. MicroRNA targeting specificity in mammals: Determinants beyond seed pairing. Mol. Cell 2007, 27, 91-105. [CrossRef]

32. Jonas, S.; Izaurralde, E. Towards a molecular understanding of microRNA-mediated gene silencing. Nat. Rev. Genet. 2015, 16, 421-433. [CrossRef]

33. Hata, A.; Kashima, R. Dysregulation of microRNA biogenesis machinery in cancer. Crit. Rev. Biochem. Mol. Biol. 2016, 51, 121-134. [CrossRef] [PubMed]

34. Claus, R.; Lucas, D.M.; Stilgenbauer, S.; Ruppert, A.S.; Yu, L.; Zucknick, M.; Mertens, D.; Bühler, A.; Oakes, C.C.; Larson, R.A.; et al. Quantitative DNA methylation analysis identifies a single CpG dinucleotide important for ZAP-70 expression and predictive of prognosis in chronic lymphocytic leukemia. J. Clin. Oncol. 2012, 30, 2483-2491. [CrossRef] [PubMed]

35. Döhner, H.; Stilgenbauer, S.; Benner, A.; Leupolt, E.; Kröber, A.; Bullinger, L.; Döhner, K.; Bentz, M.; Lichter, P. Genomic aberrations and survival in chronic lymphocytic leukemia. N. Engl. J. Med. 2000, 343, 1910-1916. [CrossRef]

36. Zenz, T.; Mertens, D.; Döhner, H.; Stilgenbauer, S. Importance of genetics in chronic lymphocytic leukemia. Blood Rev. 2011, 25, 131-137. [CrossRef] [PubMed]

37. Kay, N.E.; O'Brien, S.M.; Pettitt, A.R.; Stilgenbauer, S. The role of prognostic factors in assessing 'high-risk' subgroups of patients with chronic lymphocytic leukemia. Leukemia 2007, 21, 1885-1891. [CrossRef] [PubMed]

38. Morilla, A.; Gonzalez de Castro, D.; Del Giudice, I.; Osuji, N.; Else, M.; Morilla, R.; Brito Babapulle, V.; Rudenko, H.; Matutes, E.; Dearden, C.; et al. Combinations of ZAP-70, CD38 and IGHV mutational status as predictors of time to first treatment in CLL. Leuk Lymphoma 2008, 49, 2108-2115. [CrossRef]

39. Pekarsky, Y.; Balatti, V.; Croce, C.M. BCL2 and miR-15/16: From gene discovery to treatment. Cell Death Differ. 2018, 25, 21-26. [CrossRef] [PubMed]

40. De Oliveira, J.C.; Scrideli, C.A.; Brassesco, M.S.; Morales, A.G.; Pezuk, J.A.; Queiroz, R.e.P.; Yunes, J.A.; Brandalise, S.R.; Tone, L.G. Differential miRNA expression in childhood acute lymphoblastic leukemia and association with clinical and biological features. Leuk Res. 2012, 36, 293-298. [CrossRef]

41. Li, X.J.; Luo, X.Q.; Han, B.W.; Duan, F.T.; Wei, P.P.; Chen, Y.Q. MicroRNA-100/99a, deregulated in acute lymphoblastic leukaemia, suppress proliferation and promote apoptosis by regulating the FKBP51 and IGF1R/mTOR signalling pathways. Br J. Cancer 2013, 109, 2189-2198. [CrossRef]

42. Balatti, V.; Tomasello, L.; Rassenti, L.Z.; Veneziano, D.; Nigita, G.; Wang, H.Y.; Thorson, J.A.; Kipps, T.J.; Pekarsky, Y.; Croce, C.M. miR-125a and miR-34a expression predicts Richter syndrome in chronic lymphocytic leukemia patients. Blood 2018, 132, 2179-2182. [CrossRef] [PubMed]

43. Swellam, M.; Hashim, M.; Mahmoud, M.S.; Ramadan, A.; Hassan, N.M. Aberrant Expression of Some Circulating miRNAs in Childhood Acute Lymphoblastic Leukemia. Biochem. Genet. 2018, 56, 283-294. [CrossRef] [PubMed]

44. Flamant, S.; Ritchie, W.; Guilhot, J.; Holst, J.; Bonnet, M.L.; Chomel, J.C.; Guilhot, F.; Turhan, A.G.; Rasko, J.E. Micro-RNA response to imatinib mesylate in patients with chronic myeloid leukemia. Haematologica 2010, 95, 1325-1333. [CrossRef] [PubMed]

45. Machová Poláková, K.; Lopotová, T.; Klamová, H.; Burda, P.; Trněný, M.; Stopka, T.; Moravcová, J. Expression patterns of microRNAs associated with CML phases and their disease related targets. Mol. Cancer 2011, 10, 41. [CrossRef]

46. Suresh, S.; McCallum, L.; Lu, W.; Lazar, N.; Perbal, B.; Irvine, A.E. MicroRNAs 130a/b are regulated by BCR-ABL and downregulate expression of CCN3 in CML. J. Cell Commun. Signal 2011, 5, 183-191. [CrossRef]

47. McLaughlin, J.; Cheng, D.; Singer, O.; Lukacs, R.U.; Radu, C.G.; Verma, I.M.; Witte, O.N. Sustained suppression of Bcr-Abl-driven lymphoid leukemia by microRNA mimics. Proc. Natl. Acad. Sci. USA 2007, 104, 20501-20506. [CrossRef]

48. Ferreira, A.F.; Moura, L.G.; Tojal, I.; Ambrósio, L.; Pinto-Simões, B.; Hamerschlak, N.; Calin, G.A.; Ivan, C.; Covas, D.T.; Kashima, S.; et al. ApoptomiRs expression modulated by BCR-ABL is linked to CML progression and imatinib resistance. Blood Cells Mol. Dis. 2014, 53, 47-55. [CrossRef]

49. Bueno, M.J.; Pérez de Castro, I.; Gómez de Cedrón, M.; Santos, J.; Calin, G.A.; Cigudosa, J.C.; Croce, C.M.; Fernández-Piqueras, J.; Malumbres, M. Genetic and epigenetic silencing of microRNA-203 enhances ABL1 and BCR-ABL1 oncogene expression. Cancer Cell 2008, 13, 496-506. [CrossRef]

50. Srutova, K.; Curik, N.; Burda, P.; Savvulidi, F.; Silvestri, G.; Trotta, R.; Klamova, H.; Pecherkova, P.; Sovova, Z.; Koblihova, J.; et al. BCR-ABL1 mediated miR-150 downregulation through MYC contributed to myeloid differentiation block and drug resistance in chronic myeloid leukemia. Haematologica 2018, 103, 2016-2025. [CrossRef]

51. Jabbour, E.; Kantarjian, H. Chronic myeloid leukemia: 2018 update on diagnosis, therapy and monitoring. Am. J. Hematol. 2018, 93, 442-459. [CrossRef] 
52. Rassenti, L.Z.; Balatti, V.; Ghia, E.M.; Palamarchuk, A.; Tomasello, L.; Fadda, P.; Pekarsky, Y.; Widhopf, G.F.; Kipps, T.J.; Croce, C.M. MicroRNA dysregulation to identify therapeutic target combinations for chronic lymphocytic leukemia. Proc. Natl. Acad. Sci. USA 2017, 114, 10731-10736. [CrossRef] [PubMed]

53. Lovat, F.; Nigita, G.; Distefano, R.; Nakamura, T.; Gasparini, P.; Tomasello, L.; Fadda, P.; Ibrahimova, N.; Catricalà, S.; Palamarchuk, A.; et al. Combined loss of function of two different loci of miR-15/16 drives the pathogenesis of acute myeloid leukemia. Proc. Natl. Acad. Sci. USA 2020, 117, 12332-12340. [CrossRef] [PubMed]

54. Lovat, F.; Fassan, M.; Gasparini, P.; Rizzotto, L.; Cascione, L.; Pizzi, M.; Vicentini, C.; Balatti, V.; Palmieri, D.; Costinean, S.; et al. miR-15b/16-2 deletion promotes B-cell malignancies. Proc. Natl. Acad. Sci. USA 2015, 112, 11636-11641. [CrossRef]

55. Lovat, F.; Fassan, M.; Sacchi, D.; Ranganathan, P.; Palamarchuk, A.; Bill, M.; Karunasiri, M.; Gasparini, P.; Nigita, G.; Distefano, R.; et al. Knockout of both miR-15/16 loci induces acute myeloid leukemia. Proc. Natl. Acad. Sci. USA 2018, 115, 13069-13074. [CrossRef]

56. Li, Z.; Lu, J.; Sun, M.; Mi, S.; Zhang, H.; Luo, R.T.; Chen, P.; Wang, Y.; Yan, M.; Qian, Z.; et al. Distinct microRNA expression profiles in acute myeloid leukemia with common translocations. Proc. Natl. Acad. Sci. USA 2008, 105, 15535-15540. [CrossRef] [PubMed]

57. Yang, Y.L.; Yen, C.T.; Pai, C.H.; Chen, H.Y.; Yu, S.L.; Lin, C.Y.; Hu, C.Y.; Jou, S.T.; Lin, D.T.; Lin, S.R.; et al. A Double Negative Loop Comprising ETV6/RUNX1 and MIR181A1 Contributes to Differentiation Block in t(12;21)-Positive Acute Lymphoblastic Leukemia. PLoS ONE 2015, 10, e0142863. [CrossRef] [PubMed]

58. Wang, Y.; Yan, P.; Liu, Z.; Yang, X.; Shen, Z.; Bai, H.; Wang, J.; Wang, Z. MEK inhibitor can reverse the resistance to bevacizumab in A549 cells harboring Kirsten rat sarcoma oncogene homolog mutation. Thorac. Cancer 2016, 7, 279-287. [CrossRef]

59. Nabhan, M.; Louka, M.L.; Khairy, E.; Tash, F.; Ali-Labib, R.; El-Habashy, S. MicroRNA-181a and its target Smad 7 as potential biomarkers for tracking child acute lymphoblastic leukemia. Gene 2017, 628, 253-258. [CrossRef]

60. Haque, S.; Vaiselbuh, S.R. Silencing of Exosomal miR-181a Reverses Pediatric Acute Lymphocytic Leukemia Cell Proliferation. Pharmaceuticals 2020, 13, 241. [CrossRef]

61. Visone, R.; Veronese, A.; Rassenti, L.Z.; Balatti, V.; Pearl, D.K.; Acunzo, M.; Volinia, S.; Taccioli, C.; Kipps, T.J.; Croce, C.M miR-181b is a biomarker of disease progression in chronic lymphocytic leukemia. Blood 2011, 118, 3072-3079. [CrossRef]

62. Gimenes-Teixeira, H.L.; Lucena-Araujo, A.R.; Dos Santos, G.A.; Zanette, D.L.; Scheucher, P.S.; Oliveira, L.C.; Dalmazzo, L.F.; Silva-Júnior, W.A.; Falcão, R.P.; Rego, E.M. Increased expression of miR-221 is associated with shorter overall survival in T-cell acute lymphoid leukemia. Exp. Hematol. Oncol. 2013, 2, 10. [CrossRef]

63. Santanam, U.; Zanesi, N.; Efanov, A.; Costinean, S.; Palamarchuk, A.; Hagan, J.P.; Volinia, S.; Alder, H.; Rassenti, L.; Kipps, T.; et al. Chronic lymphocytic leukemia modeled in mouse by targeted miR-29 expression. Proc. Natl. Acad. Sci. USA 2010, 107, 12210-12215. [CrossRef]

64. Ngankeu, A.; Ranganathan, P.; Havelange, V.; Nicolet, D.; Volinia, S.; Powell, B.L.; Kolitz, J.E.; Uy, G.L.; Stone, R.M.; Kornblau, S.M.; et al. Discovery and functional implications of a miR-29b-1/miR-29a cluster polymorphism in acute myeloid leukemia. Oncotarget 2018, 9, 4354-4365. [CrossRef] [PubMed]

65. Zaidi, S.K.; Perez, A.W.; White, E.S.; Lian, J.B.; Stein, J.L.; Stein, G.S. An AML1-ETO/miR-29b-1 regulatory circuit modulates phenotypic properties of acute myeloid leukemia cells. Oncotarget 2017, 8, 39994-40005. [CrossRef] [PubMed]

66. Zenz, T.; Mohr, J.; Eldering, E.; Kater, A.P.; Bühler, A.; Kienle, D.; Winkler, D.; Dürig, J.; van Oers, M.H.; Mertens, D.; et al. miR-34a as part of the resistance network in chronic lymphocytic leukemia. Blood 2009, 113, 3801-3808. [CrossRef] [PubMed]

67. Rücker, F.G.; Russ, A.C.; Cocciardi, S.; Kett, H.; Schlenk, R.F.; Botzenhardt, U.; Langer, C.; Krauter, J.; Fröhling, S.; Schlegelberger, B.; et al. Altered miRNA and gene expression in acute myeloid leukemia with complex karyotype identify networks of prognostic relevance. Leukemia 2013, 27, 353-361. [CrossRef]

68. Weng, H.; Lal, K.; Yang, F.F.; Chen, J. The pathological role and prognostic impact of miR-181 in acute myeloid leukemia. Cancer Genet 2015, 208, 225-229. [CrossRef]

69. Fabbri, M.; Bottoni, A.; Shimizu, M.; Spizzo, R.; Nicoloso, M.S.; Rossi, S.; Barbarotto, E.; Cimmino, A.; Adair, B.; Wojcik, S.E.; et al. Association of a microRNA/TP53 feedback circuitry with pathogenesis and outcome of B-cell chronic lymphocytic leukemia. JAMA 2011, 305, 59-67. [CrossRef]

70. Cuneo, A.; Bigoni, R.; Rigolin, G.M.; Roberti, M.G.; Bardi, A.; Cavazzini, F.; Milani, R.; Minotto, C.; Tieghi, A.; Della Porta, M.; et al. Late appearance of the 11q22.3-23.1 deletion involving the ATM locus in B-cell chronic lymphocytic leukemia and related disorders. Clinico-biological significance. Haematologica 2002, 87, 44-51.

71. Skowronska, A.; Austen, B.; Powell, J.E.; Weston, V.; Oscier, D.G.; Dyer, M.J.; Matutes, E.; Pratt, G.; Fegan, C.; Moss, P.; et al. ATM germline heterozygosity does not play a role in chronic lymphocytic leukemia initiation but influences rapid disease progression through loss of the remaining ATM allele. Haematologica 2012, 97, 142-146. [CrossRef]

72. Greipp, P.T.; Smoley, S.A.; Viswanatha, D.S.; Frederick, L.S.; Rabe, K.G.; Sharma, R.G.; Slager, S.L.; Van Dyke, D.L.; Shanafelt, T.D.; Tschumper, R.C.; et al. Patients with chronic lymphocytic leukaemia and clonal deletion of both $17 \mathrm{p} 13.1$ and $11 \mathrm{q} 22.3$ have a very poor prognosis. Br. J. Haematol. 2013, 163, 326-333. [CrossRef]

73. Lin, K.; Lane, B.; Carter, A.; Johnson, G.G.; Onwuazor, O.; Oates, M.; Zenz, T.; Stilgenbauer, S.; Atherton, M.; Douglas, A.; et al The gene expression signature associated with TP53 mutation/deletion in chronic lymphocytic leukaemia is dominated by the under-expression of TP53 and other genes on chromosome 17p. Br. J. Haematol. 2013, 160, 53-62. [CrossRef] 
74. González-Gascón, Y.; Marín, I.; Hernández-Sanchez, M.; Rodríguez-Vicente, A.E.; Puiggros, A.; Collado, R.; Luño, E.; González, T.; Ruiz-Xivillé, N.; Ortega, M.; et al. Characterizing patients with multiple chromosomal aberrations detected by FISH in chronic lymphocytic leukemia. Leuk Lymphoma 2018, 59, 633-642. [CrossRef] [PubMed]

75. Calin, G.A.; Cimmino, A.; Fabbri, M.; Ferracin, M.; Wojcik, S.E.; Shimizu, M.; Taccioli, C.; Zanesi, N.; Garzon, R.; Aqeilan, R.I.; et al. MiR-15a and miR-16-1 cluster functions in human leukemia. Proc. Natl. Acad. Sci. USA 2008, 105, 5166-5171. [CrossRef]

76. Robinson, V.L. Rethinking the central dogma: Noncoding RNAs are biologically relevant. Urol. Oncol. 2009, 27, 304-306. [CrossRef]

77. Veronese, A.; Pepe, F.; Chiacchia, J.; Pagotto, S.; Lanuti, P.; Veschi, S.; Di Marco, M.; D’Argenio, A.; Innocenti, I.; Vannata, B.; et al. Allele-specific loss and transcription of the miR-15a/16-1 cluster in chronic lymphocytic leukemia. Leukemia 2015, 29, 86-95. [CrossRef] [PubMed]

78. Zenz, T.; Benner, A.; Döhner, H.; Stilgenbauer, S. Chronic lymphocytic leukemia and treatment resistance in cancer: The role of the p53 pathway. Cell Cycle 2008, 7, 3810-3814. [CrossRef] [PubMed]

79. Zenz, T.; Häbe, S.; Denzel, T.; Mohr, J.; Winkler, D.; Bühler, A.; Sarno, A.; Groner, S.; Mertens, D.; Busch, R.; et al. Detailed analysis of p53 pathway defects in fludarabine-refractory chronic lymphocytic leukemia (CLL): Dissecting the contribution of 17p deletion, TP53 mutation, p53-p21 dysfunction, and miR34a in a prospective clinical trial. Blood 2009, 114, 2589-2597. [CrossRef]

80. Visone, R.; Rassenti, L.Z.; Veronese, A.; Taccioli, C.; Costinean, S.; Aguda, B.D.; Volinia, S.; Ferracin, M.; Palatini, J.; Balatti, V.; et al. Karyotype-specific microRNA signature in chronic lymphocytic leukemia. Blood 2009, 114, 3872-3879. [CrossRef]

81. Visone, R.; Veronese, A.; Balatti, V.; Croce, C.M. MiR-181b: New perspective to evaluate disease progression in chronic lymphocytic leukemia. Oncotarget 2012, 3, 195-202. [CrossRef] [PubMed]

82. Bresin, A.; Callegari, E.; D’Abundo, L.; Cattani, C.; Bassi, C.; Zagatti, B.; Narducci, M.G.; Caprini, E.; Pekarsky, Y.; Croce, C.M.; et al. miR-181b as a therapeutic agent for chronic lymphocytic leukemia in the E $\mu$-TCL1 mouse model. Oncotarget 2015, 6 , 19807-19818. [CrossRef] [PubMed]

83. Haussecker, D.; Huang, Y.; Lau, A.; Parameswaran, P.; Fire, A.Z.; Kay, M.A. Human tRNA-derived small RNAs in the global regulation of RNA silencing. RNA 2010, 16, 673-695. [CrossRef] [PubMed]

84. Veneziano, D.; Tomasello, L.; Balatti, V.; Palamarchuk, A.; Rassenti, L.Z.; Kipps, T.J.; Pekarsky, Y.; Croce, C.M. Dysregulation of different classes of tRNA fragments in chronic lymphocytic leukemia. Proc. Natl. Acad. Sci. USA 2019, 116, 24252-24258 [CrossRef] [PubMed]

85. Balatti, V.; Pekarsky, Y.; Croce, C.M. Role of the tRNA-Derived Small RNAs in Cancer: New Potential Biomarkers and Target for Therapy. In Advances in Cancer Research; Croce, C.M., Fisher, P.B., Eds.; Elsevier: Cambridge, MA, USA, 2017; Volume 135, pp. 173-187. [CrossRef]

86. Pepe, F.; Balatti, V. Role of Non-Coding RNAs in the Development of Targeted Therapy and Immunotherapy Approaches for Chronic Lymphocytic Leukemia. J. Clin. Med. 2020, 9, 593. [CrossRef]

87. Willemse, M.J.; Seriu, T.; Hettinger, K.; d'Aniello, E.; Hop, W.C.; Panzer-Grümayer, E.R.; Biondi, A.; Schrappe, M.; Kamps, W.A.; Masera, G.; et al. Detection of minimal residual disease identifies differences in treatment response between T-ALL and precursor B-ALL. Blood 2002, 99, 4386-4393. [CrossRef]

88. Copelan, E.A.; McGuire, E.A. The biology and treatment of acute lymphoblastic leukemia in adults. Blood 1995, 85, 1151-1168 [CrossRef]

89. Malard, F.; Mohty, M. Acute lymphoblastic leukaemia. Lancet 2020, 395, 1146-1162. [CrossRef]

90. Vardiman, J.W.; Thiele, J.; Arber, D.A.; Brunning, R.D.; Borowitz, M.J.; Porwit, A.; Harris, N.L.; Le Beau, M.M.; HellströmLindberg, E.; Tefferi, A.; et al. The 2008 revision of the World Health Organization (WHO) classification of myeloid neoplasms and acute leukemia: Rationale and important changes. Blood 2009, 114, 937-951. [CrossRef]

91. Terwilliger, T.; Abdul-Hay, M. Acute lymphoblastic leukemia: A comprehensive review and 2017 update. Blood Cancer J. 2017, 7, e577. [CrossRef]

92. Schotte, D.; Chau, J.C.; Sylvester, G.; Liu, G.; Chen, C.; van der Velden, V.H.; Broekhuis, M.J.; Peters, T.C.; Pieters, R.; den Boer, M.L. Identification of new microRNA genes and aberrant microRNA profiles in childhood acute lymphoblastic leukemia. Leukemia 2009, 23, 313-322. [CrossRef] [PubMed]

93. Almeida, R.S.; Costa, E.; Silva, M.; Coutinho, L.L.; Garcia Gomes, R.; Pedrosa, F.; Massaro, J.D.; Donadi, E.A.; Lucena-Silva, N. MicroRNA expression profiles discriminate childhood T- from B-acute lymphoblastic leukemia. Hematol. Oncol. $2019,37,103-112$. [CrossRef] [PubMed]

94. Luan, C.; Yang, Z.; Chen, B. The functional role of microRNA in acute lymphoblastic leukemia: Relevance for diagnosis, differential diagnosis, prognosis, and therapy. Onco. Targets Ther. 2015, 8, 2903-2914. [CrossRef] [PubMed]

95. Fulci, V.; Colombo, T.; Chiaretti, S.; Messina, M.; Citarella, F.; Tavolaro, S.; Guarini, A.; Foà, R.; Macino, G. Characterization of B- and T-lineage acute lymphoblastic leukemia by integrated analysis of MicroRNA and mRNA expression profiles. Genes Chromosomes Cancer 2009, 48, 1069-1082. [CrossRef]

96. Mavrakis, K.J.; Van Der Meulen, J.; Wolfe, A.L.; Liu, X.; Mets, E.; Taghon, T.; Khan, A.A.; Setty, M.; Setti, M.; Rondou, P.; et al. A cooperative microRNA-tumor suppressor gene network in acute T-cell lymphoblastic leukemia (T-ALL). Nat. Genet. 2011, 43, 673-678. [CrossRef]

97. Lu, J.; Getz, G.; Miska, E.A.; Alvarez-Saavedra, E.; Lamb, J.; Peck, D.; Sweet-Cordero, A.; Ebert, B.L.; Mak, R.H.; Ferrando, A.A.; et al. MicroRNA expression profiles classify human cancers. Nature 2005, 435, 834-838. [CrossRef] [PubMed] 
98. Verduci, L.; Azzalin, G.; Gioiosa, S.; Carissimi, C.; Laudadio, I.; Fulci, V.; Macino, G. microRNA-181a enhances cell proliferation in acute lymphoblastic leukemia by targeting EGR1. Leuk Res. 2015, 39, 479-485. [CrossRef]

99. Löwenberg, B.; Downing, J.R.; Burnett, A. Acute myeloid leukemia. N. Engl. J. Med. 1999, 341, 1051-1062. [CrossRef]

100. Stubbins, R.J.; Karsan, A. Differentiation therapy for myeloid malignancies: Beyond cytotoxicity. Blood Cancer J. $2021,11,193$. [CrossRef]

101. Rosenfeld, C.; List, A. A hypothesis for the pathogenesis of myelodysplastic syndromes: Implications for new therapies. Leukemia 2000, 14, 2-8. [CrossRef]

102. Vardiman, J.W.; Harris, N.L.; Brunning, R.D. The World Health Organization (WHO) classification of the myeloid neoplasms. Blood 2002, 100, 2292-2302. [CrossRef]

103. De Kouchkovsky, I.; Abdul-Hay, M. Acute myeloid leukemia: A comprehensive review and 2016 update. Blood Cancer J. 2016, 6, e441. [CrossRef] [PubMed]

104. Kumar, C.C. Genetic abnormalities and challenges in the treatment of acute myeloid leukemia. Genes Cancer 2011, 2, 95-107. [CrossRef] [PubMed]

105. Estey, E.; Döhner, H. Acute myeloid leukaemia. Lancet 2006, 368, 1894-1907. [CrossRef]

106. Zampini, M.; Tregnago, C.; Bisio, V.; Simula, L.; Borella, G.; Manara, E.; Zanon, C.; Zonta, F.; Serafin, V.; Accordi, B.; et al Epigenetic heterogeneity affects the risk of relapse in children with $\mathrm{t}(8 ; 21) \mathrm{RUNX1-RUNX1T1-rearranged} \mathrm{AML.} \mathrm{Leukemia} \mathrm{2018,} \mathrm{32,}$ 1124-1134. [CrossRef]

107. Meyer, C.; Burmeister, T.; Gröger, D.; Tsaur, G.; Fechina, L.; Renneville, A.; Sutton, R.; Venn, N.C.; Emerenciano, M.; Pombo-deOliveira, M.S.; et al. The MLL recombinome of acute leukemias in 2017. Leukemia 2018, 32, 273-284. [CrossRef] [PubMed]

108. Soni, A.; Djokic, M.; Hou, J.Z.; Redner, R.L.; Boyiadzis, M. Outcomes of acute myeloid leukemia with $\mathrm{t}(15 ; 17)$ not associated with acute promyelocytic leukemia. Leuk Lymphoma 2015, 56, 3236-3239. [CrossRef]

109. Garzon, R.; Volinia, S.; Liu, C.G.; Fernandez-Cymering, C.; Palumbo, T.; Pichiorri, F.; Fabbri, M.; Coombes, K.; Alder, H.; Nakamura, T.; et al. MicroRNA signatures associated with cytogenetics and prognosis in acute myeloid leukemia. Blood 2008, 111, 3183-3189. [CrossRef]

110. Garzon, R.; Liu, S.; Fabbri, M.; Liu, Z.; Heaphy, C.E.; Callegari, E.; Schwind, S.; Pang, J.; Yu, J.; Muthusamy, N.; et al. MicroRNA$29 \mathrm{~b}$ induces global DNA hypomethylation and tumor suppressor gene reexpression in acute myeloid leukemia by targeting directly DNMT3A and 3B and indirectly DNMT1. Blood 2009, 113, 6411-6418. [CrossRef]

111. Gong, J.N.; Yu, J.; Lin, H.S.; Zhang, X.H.; Yin, X.L.; Xiao, Z.; Wang, F.; Wang, X.S.; Su, R.; Shen, C.; et al. The role, mechanism and potentially therapeutic application of microRNA-29 family in acute myeloid leukemia. Cell Death Differ. 2014, 21, 100-112. [CrossRef] [PubMed]

112. Pulikkan, J.A.; Peramangalam, P.S.; Dengler, V.; Ho, P.A.; Preudhomme, C.; Meshinchi, S.; Christopeit, M.; Nibourel, O.; MüllerTidow, C.; Bohlander, S.K.; et al. C/EBP $\alpha$ regulated microRNA-34a targets E2F3 during granulopoiesis and is down-regulated in AML with CEBPA mutations. Blood 2010, 116, 5638-5649. [CrossRef] [PubMed]

113. Schwind, S.; Maharry, K.; Radmacher, M.D.; Mrózek, K.; Holland, K.B.; Margeson, D.; Whitman, S.P.; Hickey, C.; Becker, H.; Metzeler, K.H.; et al. Prognostic significance of expression of a single microRNA, miR-181a, in cytogenetically normal acute myeloid leukemia: A Cancer and Leukemia Group B study. J. Clin. Oncol. 2010, 28, 5257-5264. [CrossRef]

114. Marcucci, G.; Maharry, K.; Radmacher, M.D.; Mrózek, K.; Vukosavljevic, T.; Paschka, P.; Whitman, S.P.; Langer, C.; Baldus, C.D.; Liu, C.G.; et al. Prognostic significance of, and gene and microRNA expression signatures associated with, CEBPA mutations in cytogenetically normal acute myeloid leukemia with high-risk molecular features: A Cancer and Leukemia Group B Study. J. Clin. Oncol. 2008, 26, 5078-5087. [CrossRef]

115. Li, Z.; Huang, H.; Li, Y.; Jiang, X.; Chen, P.; Arnovitz, S.; Radmacher, M.D.; Maharry, K.; Elkahloun, A.; Yang, X.; et al. Up-regulation of a HOXA-PBX3 homeobox-gene signature following down-regulation of miR-181 is associated with adverse prognosis in patients with cytogenetically abnormal AML. Blood 2012, 119, 2314-2324. [CrossRef] [PubMed]

116. Lu, F.; Zhang, J.; Ji, M.; Li, P.; Du, Y.; Wang, H.; Zang, S.; Ma, D.; Sun, X.; Ji, C. miR-181b increases drug sensitivity in acute myeloid leukemia via targeting HMGB1 and Mcl-1. Int. J. Oncol. 2014, 45, 383-392. [CrossRef] [PubMed]

117. Rowley, J.D. Letter: A new consistent chromosomal abnormality in chronic myelogenous leukaemia identified by quinacrine fluorescence and Giemsa staining. Nature 1973, 243, 290-293. [CrossRef] [PubMed]

118. Melo, J.V. The diversity of BCR-ABL fusion proteins and their relationship to leukemia phenotype. Blood 1996, 88, 2375-2384 [CrossRef]

119. Pendergast, A.M.; Quilliam, L.A.; Cripe, L.D.; Bassing, C.H.; Dai, Z.; Li, N.; Batzer, A.; Rabun, K.M.; Der, C.J.; Schlessinger, J. BCR-ABL-induced oncogenesis is mediated by direct interaction with the SH2 domain of the GRB-2 adaptor protein. Cell 1993, 75, 175-185. [CrossRef]

120. Jabbour, E.J.; Hughes, T.P.; Cortés, J.E.; Kantarjian, H.M.; Hochhaus, A. Potential mechanisms of disease progression and management of advanced-phase chronic myeloid leukemia. Leuk Lymphoma 2014, 55, 1451-1462. [CrossRef]

121. Melo, J.V.; Barnes, D.J. Chronic myeloid leukaemia as a model of disease evolution in human cancer. Nat. Rev. Cancer 2007, 7, 441-453. [CrossRef] [PubMed]

122. Vigneri, P.; Wang, J.Y. Induction of apoptosis in chronic myelogenous leukemia cells through nuclear entrapment of BCR-ABL tyrosine kinase. Nat. Med. 2001, 7, 228-234. [CrossRef] [PubMed]

123. Gambacorti-Passerini, C. Part I: Milestones in personalised medicine-imatinib. Lancet Oncol. 2008, 9, 600. [CrossRef] 
124. Hughes, T.P.; Kaeda, J.; Branford, S.; Rudzki, Z.; Hochhaus, A.; Hensley, M.L.; Gathmann, I.; Bolton, A.E.; van Hoomissen, I.C.; Goldman, J.M.; et al. Frequency of major molecular responses to imatinib or interferon alfa plus cytarabine in newly diagnosed chronic myeloid leukemia. N. Engl. J. Med. 2003, 349, 1423-1432. [CrossRef] [PubMed]

125. Soverini, S.; Martinelli, G.; Rosti, G.; Bassi, S.; Amabile, M.; Poerio, A.; Giannini, B.; Trabacchi, E.; Castagnetti, F.; Testoni, N.; et al. ABL mutations in late chronic phase chronic myeloid leukemia patients with up-front cytogenetic resistance to imatinib are associated with a greater likelihood of progression to blast crisis and shorter survival: A study by the GIMEMA Working Party on Chronic Myeloid Leukemia. J. Clin. Oncol. 2005, 23, 4100-4109. [CrossRef]

126. Alves, R.; Gonçalves, A.C.; Jorge, J.; Marques, G.; Luís, D.; Ribeiro, A.B.; Freitas-Tavares, P.; Oliveiros, B.; Almeida, A.M.; Sarmento-Ribeiro, A.B. MicroRNA signature refine response prediction in CML. Sci. Rep. 2019, 9, 9666. [CrossRef]

127. Agirre, X.; Jiménez-Velasco, A.; San José-Enériz, E.; Garate, L.; Bandrés, E.; Cordeu, L.; Aparicio, O.; Saez, B.; Navarro, G.; Vilas-Zornoza, A.; et al. Down-regulation of hsa-miR-10a in chronic myeloid leukemia CD34+ cells increases USF2-mediated cell growth. Mol. Cancer Res. 2008, 6, 1830-1840. [CrossRef] [PubMed]

128. San José-Enériz, E.; Román-Gómez, J.; Jiménez-Velasco, A.; Garate, L.; Martin, V.; Cordeu, L.; Vilas-Zornoza, A.; Rodríguez-Otero, P.; Calasanz, M.J.; Prósper, F.; et al. MicroRNA expression profiling in Imatinib-resistant Chronic Myeloid Leukemia patients without clinically significant ABL1-mutations. Mol. Cancer 2009, 8, 69. [CrossRef]

129. Lovat, F.; Gasparini, P.; Nigita, G.; Larkin, K.; Byrd, J.C.; Minden, M.D.; Andreeff, M.; Carter, B.Z.; Croce, C.M. Loss of expression of both miR-15/16 loci in CML transition to blast crisis. Proc. Natl. Acad. Sci. USA 2021, 118. [CrossRef]

130. Tsujimoto, Y.; Finger, L.R.; Yunis, J.; Nowell, P.C.; Croce, C.M. Cloning of the chromosome breakpoint of neoplastic B cells with the $\mathrm{t}(14 ; 18)$ chromosome translocation. Science 1984, 226, 1097-1099. [CrossRef] 